\title{
PENDIDIKAN NILAI SEBAGAI SUATU STRATEGI DALAM PEMBENTUKAN KEPRIBADIAN SISWA
}

\author{
DYAH KUSUMA WINDRATI \\ 08128043966 \\ dyahkusumawindrati@yahoo.com \\ Program Studi Pendidikan Matematika, Fakultas Teknik, Matematika dan Ilmu Pengetahuan Alam \\ Universitas Indraprasta PGRI (UNINDRA) \\ Tanjung Barat, Jagakarsa, Jakarta Selatan
}

\begin{abstract}
Value education serves to help students understand, appreciate, make the right decisions in a variety of personal problems, families, communities and countries that are expected to eliminate the arrogance that often occur. The value planting approaches (inculcation approach) is an approach that gives emphasis on the cultivation of social values in students. While the method used in this learning process are: Modeling, positive reinforcement, and negative, simulations, role games, etc. There are two views about the value. First, the value is the highest measure of human behavior and upheld by a group of people and used as guidance in attitude and behavior. Both values are dependent on fishing and feelings of people who are subject to certain phenomena. Value education methods that include: 1) method of advising (moralizing), 2) method of all to let 3) methods of model (modeling), 4) method of VCT (Value Clarification Technique). The concept of ideals in education according to Ki Hajar Dewantara main emphasis is ' ing ngarso sung tulodo' through ing ngarso sung tulodo educators showing they ideals in the form of behavior, speech, how to get along, deeds, scolds and so on.
\end{abstract}

Keywords: Education, Behavior, Values, ideals.

\section{PENDAHULUAN}

Dewasa ini banyak pihak menuntut peningkatan intensitas dan kualitas pelaksanaan Pendidikan nilai pada lembaga pendidikan formal. Para pakar pendidikan pada umumnya sependapat tentang pentingnya upaya peningkatan pendidikan nilai pada jalur pendidikan formal. Namur demikian, ada perbedaan-perbedaan pendapat di antara mereka tentang pendekatan dan modus pendidikannya. Sebagian pakar menyarankan penggunaan pendekatan-pendekatan pendidikan moral yang dikembangkan di negaranegara barat, seperti: pendekatan perkembangan moral kognitif, pendekatan analisis nilai, dan pendekatan klarifikasi nilai. Sebagian yang lain menyarankan penggunaan pendekatan tradisional, yakni melalui penanaman nilai-nilai sosial tertentu dalam diri siswa.

Dalam Undang-undang No. 20 Tahun 2003 pasal 3 dijelaskan bahwa Pendidikan Nasional berfungsi mengembangkan kemampuan dan membentuk watak serta peradaban bangsa yang bermartabat dalam rangka mencerdaskan kehidupan bangsa, bertujuan untuk berkembangnya potensi peserta didik, agar menjadi manusia yang beriman dan bertakwa kepada Tuhan Yang Mahaesa, berakhlaq mulia, sehat, berilmu, cakap, kreatif, mandiri, dan menjadi warga Negara yang demokratis serta bertanggungjawab.

Dalam pendidikan, berbagai aspek nilai dapat digunakan sebagai pendekatan, misalnya melalui transformasi dan internalisasi nilai-nilai ke dalam dirinya, terjadilah 
kemudian dalam diri individu tersebut suatu perubahan sistem nilai atau rekonstruksi sistem nilai yang dapat mengubah moral seseorang. Diantara metode internalisasi nilai yang dianggap efektif adalah adalah melalui keteladan dan kepeloporan.

Sehubungan dengan hal tersebut di atas, maka dalam tulisan ini dikemukakan permasalahan pokok sebagai berikut : Bagaimana Peran Pendidikan Nilai Segai Suatu Strategi dalam Pembentukan Kepribadian Siswa. Untuk menjawab permasalahan ini, maka pembahasan dimulai dengan Peran Pendidikan Nilai, Pembentukan Perilaku melalui Pendidikan Keteladanan, kemudian diakhiri dengan kesimpulan.

\section{PEMBAHASAN}

\section{Peran Pendidikan Nilai}

\section{Pengertian Nilai}

Dalam Ensiklopedia Indonesia dinyatakan bahwa pembicaraan tentang nilai dalam filsafat sering dihubungkan dengan kebaikan. "Value" berasal dari kata "valere" yang berarti bernilai atau berharga, yaitu kualitas sesuatu yang membuatnya didambakan atau diidamkan orang. Dengan ungkapan lain apabila sesuatu itu dipandang baik, dirasakan bermanfaat untuk dimiliki, bermanfaat untuk dikerjakan atau bermanfaat untuk dicapai seseorang, maka akan menjadi idaman orang. Jadi sesuatu itu bernilai. Biasanya nilai berada dalam bidang etika atau estetika ( Poedjiadi, 2005:81).

Fungsi pendidikan nilai adalah membantu peserta didik untuk mengenali nilai-nilai dan menempatkan secara integral dalam konteks keseluruhan hidupnya. Pendidikan nilai juga berfungsi untuk membantu peserta didik memahami, mengapresiasikan, membuat keputusan yang tepat dalam berbagai masalah pribadi, keluarga, masyarakat dan negara yang diharapkan dapat mengeliminir sikap arogansi yang kerap kali terjadi. Dengan kata lain pendidikan nilai itu adalah pemanusiaan manusia. Manusia hanya menjadi manusia bila ia berbudi luhur, berkehendak baik serta mampu mengaktualisasikan diri dan mengembangkan budi, dan kehendaknya secara jujur, baik di keluarga, masyarakat, negara dan lingkungan di mana ia berada.

Sehubungan dengan nilai, Max Scheller dalam Atmadi \& Setiyaningsih, 2000: 73) menyajikan hirarki nilai-nilai dalam empat tingkatan sebagai berikut :

a. Nilai-nilai kenikmatan; dalam tingkatan ini terdapat deretan nilai-nilai mengenakkan, yang menyebabkan orang senang atau menderita tidak enak.

b. Nilai-nilai kehidupan ; dalam tingkatan ini terdapat nilai-nilai yang paling penting bagi kehidupan, misalnya kesehatan dan kesejahteraan umum.

c. Nilai-nilai kejiwaan ; dalam tingkatan ini terdapat nilai-nilai kejiwaan yang sama sekali tidak tergantung pada keadaan jasmani maupun lingkungannya, misalnya keindahan, kebenaran.

d. Nilai-nilai kerohanian. Nilai yang tertinggi pada tingkatan ini adalah Allah.

Merujuk pada paparan di atas maka dapat dipahami bahwa, ada dua pandangan tentang nilai. Yang pertama berpandangan bahwa nilai merupakan ukuran tertinggi dari perilaku manusia dan dijunjung tinggi oleh sekelompok masyarakat serta digunakan sebagai pedoman dalam sikap dan bertingkah laku. Pandangan kedua menganggap bahwa nilai merupakan hal yang tergantung pada penangkapan dan perasaan orang yang menjadi subyek terhadap sesuatu atau fenomena tertentu. Di sini nilai merupakan tujuan atau kehendak manusia yang ditata menurut tingkatannya. Ada yang menyusun dari nilai bawah ke atas. Pertama-tama nilai hedonis (kenikmatan), kemudian nilai utilitas (kegunaan), nilai pendidikan, nilai sosial budaya, nilai ekonomi, selanjutnya nilai estetika (keindahan), nilai susila, dan paling tinggi adalah nilai religi. 


\section{Proses Pendidikan Nilai.}

Menurut Hersh, et. al. (1980), di antara berbagai teori yang berkembang, ada enam teori yang banyak digunakan; yaitu: pendekatan pengembangan rasional, pendekatan pertimbangan, pendekatan klarifikasi nilai, pendekatan pengembangan moral kognitif, dan pendekatan perilaku sosial.

Berbeda dengan klasifikasi tersebut, Elias (1989) mengklasifikasikan berbagai teori yang berkembang menjadi tiga, yakni: pendekatan kognitif, pendekatan afektif, dan pendekatan perilaku. Klasifikasi ini menurut Rest (1992) didasarkan pada tiga unsur moralitas, yang biasa menjadi tumpuan kajian psikologi, yakni: perilaku, kognisi, dan afeksi.

Sedangkan Superka, et. al. (1976). Mengemukakan Lima pendekatan yaitu: (1) Pendekatan penanaman nilai (inculcation approach), (2) Pendekatan perkembangan moral kognitif (cognitive moral development approach), (3) Pendekatan analisis nilai (values analysis approach), (4) Pendekatan klarifikasi nilai (values clarification approach), dan (5) Pendekatan pembelajaran berbuat (action learning approach).

Pendekatan penanaman nilai (inculcation approach) adalah suatu pendekatan yang memberi penekanan pada penanaman nilai-nilai sosial dalam diri siswa. Menurut Superka et al. (1976), tujuan pendidikan nilai adalah: Pertama, diterimanya nilai-nilai sosial tertentu oleh siswa; Kedua, berubahnya nilai-nilai siswa yang tidak sesuai dengan nilai-nilai sosial yang diinginkan. Sedangkan Metoda yang digunakan dalam proses pembelajaran ini antara lain: Keteladanan, penguatan positif, dan negatif, simulasi, permainan peranan, dan lain-lain.

Pendekatan ini sebenarnya merupakan pendekatan tradisional. Banyak kritik dalam berbagai literatur barat yang ditujukan kepada pendekatan ini. Pendekatan ini dipandang indoktrinatif, tidak sesuai dengan perkembangan kehidupan demokrasi (Banks, 1985; Windmiller, 1976). Pendekatan ini dinilai mengabaikan hak anak untuk memilih nilainya sendiri secara bebas. Menurut Raths et al. (1978) kehidupan manusia berbeda karena perbedaan waktu dan tempat. Kita tidak dapat meramalkan nilai yang sesuai untuk generasi yang akan datang. Menurut beliau, setiap generasi mempunyai hak untuk menentukan nilainya sendiri. Oleh karena itu, yang perlu diajarkan kepada generasi muda bukannya nilai, melainkan proses, supaya mereka dapat menemukan nilai-nilai mereka sendiri, sesuai dengan tempat dan zamannya.

Namun demikian, Superka, et. al. (1976), menjelaskan bahwa disadari atau tidak disadari pendekatan penanaman nilai digunakan secara meluas dalam berbagai masyarakat, terutama dalam penanaman nilai-nilai agama dan nilai-nilai budaya. Para penganut agama memiliki kecenderungan yang kuat untuk menggunakan pendekatan ini dalam pelaksanaan program-program pendidikan agama.

Pendekatan ini dikatakan pendekatan perkembangan kognitif karena karakteristiknya memberikan penekanan pada aspek kognitif dan perkembangannya. Pendekatan ini mendorong siswa untuk berpikir aktif tentang masalah-masalah moral dan dalam membuat keputusan-keputusan moral. Perkembangan moral menurut pendekatan ini dilihat sebagai perkembangan tingkat berpikir dalam membuat pertimbangan moral, dari suatu tingkat yang lebih rendah menuju suatu tingkat yang lebih tinggi (Elias, 1989).

Tujuan yang ingin dicapai oleh pendekatan ini ada dua hal yang utama. Pertama, membantu siswa dalam membuat pertimbangan moral yang lebih kompleks berdasarkan kepada nilai yang lebih tinggi. Kedua, mendorong siswa untuk mendiskusikan alasanalasannya ketika memilih nilai dan posisinya dalam suatu masalah moral (Superka, et. al., 1976; Banks, 1985). 
Pada prinsipnya, pendidikan afektif atau pendidikan nilai sebenarnya secara praktis sudah ada sejak peradaban (budaya) dan kepercayaan/agama manusia tumbuh, berkembang dan dilestarikan turun temurun. Hanya saja sebagai rekayasa ilmu kependidikan menjadi kajian khusus yang baru. Pada masyarakat Indonesia pendidikan nilai baru dikenal sekitar tahun 1976-an, bahkan banyak para pakar pendidikan yang kurang yakin akan keberhasilan pencarian sosok pendidikan nilai dan pola pendidikannya.

Natonagoro dalam Atmaji \& Setiyaningsih, (2000:73). telah mengajukan usul bagaimana nilai-nilai seharusnya diajarkan kepada peserta didik dari TK sampai Perguruan Tinggi agar nilai-nilai luhur bangsa tidak hanya menjadi slogan-slogan, melainkan sungguh-sungguh diamalkan dan dihayati. Kemudian lebih lanjut Natonagoro dalam Atmaji \& Setiyaningsih, (2000:73). mengajukan empat langkah yang harus ditempuh agar pendidikan nilai berdaya guna, yaitu :

a. Para pendidik terlebih dahulu harus tahu dan memahami nilai-nilai apa saja yang akan diajarkan tentang yang tersembunyi di balik setiap bidang studi atau nilai-nilai kemanusiaan lainnya.

b. Para pendidik mentransformasikan nilai-nilai tersebut kepada peserta didik dengan sentuhan hati dan perasaan, melalui contoh-contoh konkret dan sedapat mungkin melalui keteladanan si pendidik, sehingga peserta didik dapat melihat dengan mata kepala sendiri alangkah baiknya nilai itu.

c. Langkah selanjutnya adalah membantu peserta didik untuk menginternalisasikan nilai-nilai tersebut tidah hanya dalam akal budinya, tetapi terutama dalam hati sanubari si peserta didik sehingga nilai-nilai yang dipahaminya menjadi bagian dari seluruh hidupnya.

d. Peserta didik yang telah merasa memiliki sifat-sifat dan sikap hidup sesuai dengan nilai-nilai tersebut didorong dan dibantu untuk mewujudkan atau mengungkapkannya dalam tingkah laku hidup sehari-hari.

Langkah-langkah di atas memang membawa konsekuensi bahwa seorang pendidik betul-betul harus dapat diteladani, baik kata-kata maupun perbuatan dan tingkah lakunya. Keteladanan akan meyakinkan peserta didik bahwa nilai-nilai yang disampaikan memang baik dan benar untuk dihayati dan diamalkan. Memberi teladan atau contoh apa yang diajarkan dalam kehidupan sehari-hari bukanlah soal yang mudah bagi para pendidik. Namun, tanpa memberi teladan tidak ada gunanya mengajarkan nilai-nilai pada peserta didik.

\section{Pendekatan Pendidikan Nilai.}

Pendekatan analisis nilai (values analysis approach) memberikan penekanan pada perkembangan kemampuan siswa untuk berpikir logis, dengan cara menganalisis masalah yang berhubungan dengan nilai-nilai sosial. Jika dibandingkan dengan pendekatan perkembangan kognitif, salah satu perbedaan penting antara keduanya bahwa pendekatan analisis nilai lebih menekankan pada pembahasan masalah-masalah yang memuat nilai-nilai sosial. Adapun pendekatan perkembangan kognitif memberi penekanan pada dilemma moral yang bersifat perseorangan.

Ada dua tujuan utama pendidikan moral menurut pendekatan ini. Pertama, membantu siswa untuk menggunakan kemampuan berpikir logis dan penemuan ilmiah dalam menganalisis masalah-masalah sosial, yang berhubungan dengan nilai moral tertentu. Kedua, membantu siswa untuk menggunakan proses berpikir rasional dan analitik, dalam menghubung-hubungkan dan merumuskan konsep tentang nilai-nilai mereka. (Superka, et. al. 1976).

Proses pendidikan nilai menurut pendekatan ini didasarkan pada dilemma moral, 
dengan menggunakan metoda diskusi kelompok. Diskusi itu dilaksanakan dengan memberi perhatian kepada tiga kondisi penting. Pertama, mendorong siswa menuju tingkat pertimbangan moral yang lebih tinggi. Kedua, adanya dilemma, baik dilemma hipotetikal maupun dilemma faktual berhubungan dengan nilai dalam kehidupan seharian. Ketiga, suasana yang dapat mendukung bagi berlangsungnya diskusi dengan baik (Superka, et. al. 1976; Banks, 1985).

Pendekatan perkembangan kognitif pertama kali dikemukakan oleh Dewey (Kohlberg 1971, 1977). Selanjutkan dikembangkan lagi oleh Peaget dan Kohlberg dalam Freankel, (1977); Hersh, et. al. (1980). Dewey membagi perkembangan moral anak menjadi tiga tahap (level) sebagai berikut: (1) Tahap "premoral" atau "preconventional". Dalam tahap ini tingkah laku seseorang didorong oleh desakan yang bersifat fisikal atau sosial; (2) Tahap "conventional". Dalam tahap ini seseorang mulai menerima nilai dengan sedikit kritis, berdasarkan kepada kriteria kelompoknya. (3) Tahap "autonomous". Dalam tahap ini seseorang berbuat atau bertingkah laku sesuai dengan akal pikiran dan pertimbangan dirinya sendiri.

Piaget Dalam Windmiller, (1976) mendefinisikan tingkat perkembangan moral pada anak-anak melalui pengamatan dan wawancara dengan suatu kesimpulan bahwa perkembangan kemampuan kognitif pada anak-anak mempengaruhi pertimbangan moral mereka. Sedangkan Kohlberg (1977) juga mengembangkan teorinya berdasarkan kepada asumsi-asumsi umum tentang teori perkembangan kognitif dari Dewey dan Piaget di atas. Seperti dijelaskan oleh Elias (1989), Kohlberg mendefinisikan Tingkat-tingkat perkembangan moral dimulai dari konsekuensi yang sederhana, yang berupa pengaruh kurang menyenangkan dari luar ke atas tingkah laku, sampai kepada penghayatan dan kesadaran tentang nilai-nilai kemanusian universal.

Adapula nilai-nilai abadi yang berlaku kapanpun dan dimanapun seperti kebebasan beragama, yang berarti bahwa semua manusia bebas dari paksaan baik dari perseorang maupun dari kelompok sosial, sehingga tak seorangpun boleh dipaksakan untuk bertindak bertentangan dengan imannya. Nilai terbagi menjadi dua : nilai-nilai universal, yaitu nilai yang berlaku bagi seluruh umat manusia seperti hak asasi manusia, adapula nilai particular, nilai yang hanya berlaku bagi sekelompok manusia, misalnya nilai sebuah tutur kata.

Dalam masa transisi dan derasnya arus transformasi budaya seperti sekarang ini, pendidikan nilai bukan sesuatu yang dapat ditambahkan atau boleh dikaitkan pada pendidikan begitu saja, melainkan sesuatu yang hakiki dan bahkan menduduki tempat yang amat sentral dan strategis dalam pendidikan sehingga perlu dirancang secara khusus agar dapat mentransferkan makna pendidikan nilai yang hakiki menuju peradaban bangsa. Satu hal yang harus disadari pendidik, dalam merancang kegiatan pembelajarannya, peserta didik datang ke sekolah dengan seperangkat nilai yang dibawanya dari keluarga, masyarakat, dengan berbagai corak dan warna yang berbeda. Pendidik harus mampu mengadaptasi karakteristik setiap peserta didik agar semua corak dan warna itu dapat terakumulasi secara positif. Karena sekolah merupakan sebuah potret nyata dari sebuah proses bangsa yang demokrasi.

Kaswadi, (1993:73), menjelaskan bahwa metode pendidikan nilai itu mencakup : 1) metode menasehati (moralizing) yaitu metode pendidikan nilai di mana seorang pendidik secara langsung mengajarkan sejumlah nilai yang harus menjadi pegangan hidup peserta didik. 2) metode serba membiarkan yaitu metode pendidikan nilai di mana seorang pendidik memberi kesempatan seluas-luasnya kepada peserta didik untuk menentukan pilihan terhadap nilai-nilai yang ditawarkan oleh pendidik. 3) metode model (modeling), yaitu metode pendidikan nilai di mana seorang pendidik mencoba meyakinkan peserta didik bahwa nilai tertentu itu memang baik dengan cara memberi 
contoh dirinya atau seseorang sebagai model. 4) metode VCT (Value Clarification Technique) yaitu metode pendidikan nilai yang memberi kebebasan dan kesempatan penuh peserta didik untuk mengemukakan (mengekspresikan) tanggapan, perasaan, penilaian, dan pandangannya terhadap sesuatu hal yang dijelaskan pendidik, khususnya nilai-nilai tertentu.

\section{Pembentukan Perilaku melalui Pendidikan Keteladanan.}

Keteladanan dalam pendidikan adalah metode yang efektif keberhasilannya dalam mempersiapkan dan membentuk anak di dalam moral, spiritual dan sosial. Hal ini karena pendidik adalah contoh terbaik dalam pandangan anak, yang akan ditirunya dalam tindak-tanduknya, dan tata santunnya, di sadari ataupun tidak, bahkan tercetak dalam jiwa dan perasaan anak didik.

Keteladanan menjadi faktor penting dalam hal baik-buruknya anak. Jika pendidik jujur, dapat dipercaya, berakhlaq mulia, berani dan menjauhkan diri dari perbuatanperbuatan yang bertentangan dengan agama, maka si anak akan tumbuh dalam kejujuran, terbentuk dengan akhlaq mulia, keberanian dan dalam sikap yang menjauhkan diri dari perbuatan-perbuatan yang bertentangan dengan agama. Dan jika pendidik bohong, khianat, durhaka, kikir, penakut dan hina, maka si anak akan tumbuh dalam kebohongan, khianat, durhaka, kikir, penakut dan hina.

Para ahli didik telah sepakat, bahwa salah satu tugas yang diemban oleh pendidikan adalah mewariskan nilai-nilai luhur kepada peserta didik dalam upaya membentuk kepribadian yang intelek bertanggungjawab melalui jalur pendidikan. Melalui pendidikan yang diproses secara formal, nilai-nilai luhur tersebut aka menjadi bagian dari kepribadiannya. Upaya mewariskan nilai-nilai disebut mentransformasikan nilai, sedangkan upaya memasukkan nilai-nilai disebut menginternalisasikan nilai. Kedua upaya ini dalam pendidikan dilakukan scera bersama-sama dan serempak. Untuk melaksanakan kedua kegiatan pendidikan ini, dengan memberikan suri teladan.

Konsep keteladanan dalam pendidikan Ki Hajar Dewantara tekanan utamanya yaitu 'ing ngarso sung tulodo', melalui ing ngarso sung tulodo menampilkan keteladannya dalam bentuk tingkah laku, pembicaraan, cara bergaul, amal ibadah, tegur sapa dan sebagainya. Nilai-nilai luhur yang ditampilkan tersebut akan diinternalisasikan sehingga menjadi bagian dari dirinya, yang kemudian ditampilkannya pula dalam pergaulannya di lingkungan rumah tangga atau di tempat ia bermain bersama dengan teman-temannya.

Apabila keteladanan ini kita analisis secara pedagogis, ia bertumpu pada unsurunsur pembentukan diri, karena keteladanan oleh pendidik, secara tidak langsung akan diinternalisasikan atau diserap secara langsung oleh peserta didik. Pada hakikatnya di lembaga pendidikan, pesera didik haus akan suri teladan, karena sebagaian besar hasil pembentukan kepribadian adalah keteladanan yang diamatinya dari para pendidiknya. Di rumah, keteladanan diterima dari kedua orang tuanya dan dari orang-orang dewasa dalam keluarga

Ibnu Khaldun mengutip amanah Umar bin Utbah yang disampaikan kepada guru yang akan mendidik anak-anaknya sebagai berikut : "Sebelum engkau membentuk dan membina anak-anakku, hendaklah engkau terlebih dahulu membentuk dan membina dirimu sendiri, karena anak-anakku tertuju dan tertambat kepadamu. Seluruh perbuatanmu itu baik menurut pandangan mereka. Sedangkan apa yang engkau hentikan dan tinggalkan, itu pulalah yang salah dan buruk di mata mereka". Abdullah Nasi Ulwan (1981:3), wahai orang yang mengajar orang lain, kenapa engkau tidak juga mengajari dirimu sendiri. Nilai-nilai luhur yang diajarkan kepada peserta didik bukan utuk dihafal 
menjadi ilmu pengetahuan atau kognitif, tapi adalah untuk dihayati (afektif) dan diamalkan (psikomotorik) dalam kehidupan sehari-hari.

Dalam teori pendidikan terdapat metode belajar yang dikenal dengan Learning by Doing yaitu belajar dengan mempraktekkan teori yang dipelajari. Dengan mengamalkan ilmu yang dipelajari akan menimbulkan kesan yang mendalam sehingga menjadi milik sendiri (internalisasi). Hasil belajar terletak dalam psikomotorik yaitu mempraktekkan ilmu yang dipelajari seperti nilai luhur agama di dalam praktek kehidupan sehari-hari. Keteladanan dan kepeloporan hanya beberapa cara di antara banyak cara yang dapat dilakukan oleh para pendidik untuk menanamkan nilai-nilai luhur kepada anak didiknya.

\section{KESIMPULAN}

Berdasar uraian di atas, maka penulis berkesimpulan bahwa:

1. Pendidikan nilai itu adalah pemanusiaan manusia, sehingga pendidikan nilai sangat penting kedudukannya dalam diri Manusia, karena manusia hanya menjadi manusia bila ia berbudi luhur, berkehendak baik serta mampu mengaktualisasikan diri dan mengembangkan budi, dan kehendaknya secara jujur, baik di keluarga, masyarakat, negara dan lingkungan di mana ia berada.

2. Pendidikan nilai dikembangkan dengan dua pendekatan yaitu; pendekatan Nilai (values analysis approach); dan pendekatan kognitif. Pendekatan nilai adalah suatu pendekatan yang memberikan penekanan pada perkembangan kemampuan siswa untuk berpikir logis, dengan cara menganalisis masalah yang berhubungan dengan nilai-nilai sosial. Sedangkan pendekatan kognitif adalah suatu pendekatan yang menitipberatkan pada memberi penekanan pada dilemma moral yang bersifat perseorangan.

3. Keteladanan dalam pendidikan adalah metode yang efektif dalam mempersiapkan dan membentuk anak di dalam moral, spiritual dan sosial sebagaimana yang di jelaskan oleh Ki Hajar Dewantara, bahwa konsep keteladanan dalam pendidikan tekanan utamanya yaitu 'ing ngarso sung tulodo', melalui ing ngarso sung tulodo menampilkan keteladannya dalam bentuk tingkah laku, pembicaraan, cara bergaul, amal ibadah, tegur sapa dan sebagainya.

\section{DAFTAR PUSTAKA}

Anonim. 2006. Undang-Undang RI No. 20 Tahun 2003 Tentang sistem Pendidikan Nasional

Banks, J.A. 1985. Teaching strategies for the social studies. New York: Longman.

Dwyer, Francis M, 1978. Stategis For Improving Visual Learning. Learning Services. Pensylvonia.

Elias, J. L. 1989. Moral education: secular and religious. Florida: Robert E. Krieger Publishing Co., Inc.

Hersh, R.H., Miller, J.P. \& Fielding, G.D. 1980. Model of moral education: an appraisal. New York: Longman, Inc.

Kohlberg, L. 1971. Stages of moral development as a basis of moral education. Dlm. Beck, C.M., Crittenden, B.S. \& Sullivan, E.V.(pnyt.). Moral education: interdisciplinary approaches: 23-92. New York: Newman Press.

Kohlberg, L. 1977. The cognitive-developmental approach to moral education. Dlm. Rogrs, D. Issues in adolescent psychology: 283-299. New Jersey: Printice Hall, Inc.

Mustamin dkk. 2007. Orientasi Baru Pendidikan Nilai. Makalah yang disajikan pada seminar PPs UNJ. 
Silverius, Suke. 2006 Siswa Jujur Menjadi Pemimpin Jujur. Bunga Rampai Isu-Isu Pendidikan di Indonesia. Depdiknas. Jakarta.

Silverius, Suke. 2006 Sopan Santun Pergaulan Cermin Citra Sekolah dan Bangsa. Bunga Rampai Isu-Isu Pendidikan di Indonesia.Depdiknas. Jakarta.

Superka, D.P. 1973. A typology of valuing theories and values education approaches. Doctor of Education Dissertation. University of California, Berkeley.

Superka, D.P., Ahrens, C., Hedstrom, J.E., Ford, L.J. \& Johnson, P.L. 1976. Values education sourcebook. Colorado: Social Science Education Consortium, Inc. 